\title{
Chemo-Enzymatic Synthesis of Chiral Epoxides Ethyl and Methyl (S)-3-(Oxiran-2-yl)propanoates from Renewable Levoglucosenone: An Access to Enantiopure (S)-Dairy Lactone
}

\author{
Aurélien A. M. Peru ${ }^{1,2}{ }^{\text {, Amandine L. Flourat }}{ }^{1,2}{ }^{\text {, Christian Gunawan }}{ }^{3}$, Warwick Raverty ${ }^{3}$, \\ Martyn Jevric ${ }^{4}$, Ben W. Greatrex ${ }^{4, *}$ and Florent Allais ${ }^{1,5, *}$ \\ 1 Chaire ABI-AgroParisTech, CEBB, 3 rue des Rouges Terres, 51110 Pomacle, France; \\ florent.allais@agroparistech.fr (A.A.M.P.); florent.allais@agroparistech.fr (A.L.F.) \\ 2 Institut Jean-Pierre Bourgin, INRA, AgroParisTech, CNRS, Université Paris-Saclay, RD10, \\ 78026 Versailles Cedex, France \\ 3 Circa Group Pty Ltd., 34 Norkfolk Court, Coburg, 3058 Victoria, Australia; \\ christian.gunawan@circagroup.com.au (C.G.); warwick.raverty@circagroup.com.au (W.R.) \\ 4 School of Science and Technology, University of New England, Armidale, 2350 New South Wales, Australia; \\ jevric.m@gmail.com \\ 5 UMR 782 GMPA, INRA, AgroParisTech, CNRS, Université Paris-Saclay, Avenue Lucien Brétignières, \\ 78850 Thiverval-Grignon, France \\ * Correspondence: ben.greatrex@une.edu.au (B.W.G.); florent.allais@agroparistech.fr (F.A.); \\ Tel.: +33-633-698-126 (F.A.)
}

Academic Editor: Christophe Len

Received: 28 June 2016; Accepted: 23 July 2016; Published: 29 July 2016

\begin{abstract}
Chiral epoxides—such as ethyl and methyl (S)-3-(oxiran-2-yl)propanoates ((S)-1a/1b) —are valuable precursors in many chemical syntheses. Until recently, these compounds were synthesized from glutamic acid in four steps (deamination, reduction, tosylation and epoxide formation) in low to moderate overall yield $(20 \%-50 \%)$. Moreover, this procedure requires some harmful reagents such as sodium nitrite ((eco)toxic) and borane (carcinogen). Herein, starting from levoglucosenone (LGO), a biobased chiral compound obtained through the flash pyrolysis of acidified cellulose, we propose a safer and more sustainable chemo-enzymatic synthetic pathway involving lipase-mediated Baeyer-Villiger oxidation, palladium-catalyzed hydrogenation, tosylation and treatment with sodium ethoxide/methoxide as key steps. This route afforded ethyl and methyl (S)-3-(oxiran-2-yl)propanoates in $57 \%$ overall yield, respectively. To demonstrate the potentiality of this new synthetic pathway from LGO, the synthesis of high value-added (S)-dairy lactone was undertaken from these epoxides and provided the target in $37 \%$ overall yield from LGO.
\end{abstract}

Keywords: epoxide; flavor; levoglucosenone; chirality; total synthesis

\section{Introduction}

Chiral epoxides are widely used as intermediates in organic synthesis. For example, methyl (S)-3-(oxiran-2-yl)propanoate (1a) has been employed for the synthesis of many compounds such as elicitor [1], Streptrubin B [2] or chiral $\beta$-3-substituted homopropargyl [3], thiobutyrolactone [4], $\gamma$-hydroxyesters [5], diol- $\gamma$ or $\delta$-lactones [6], keto-esters [7], (+/-)-4-alkanolides [8] (Figure 1). 


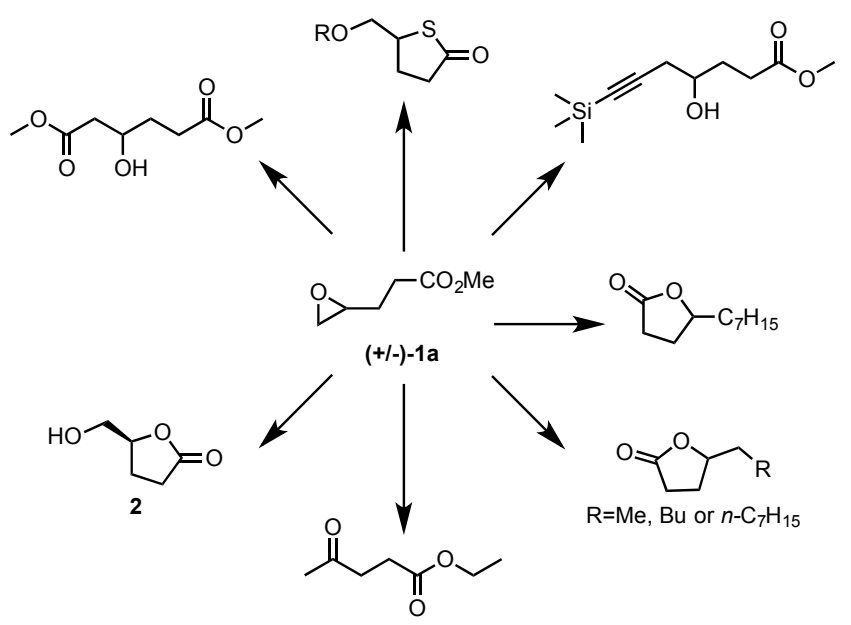

Figure 1. Some chemical intermediates synthesized from epoxide (+/-)-1a.

Classically, epoxides such as $\mathbf{1 a}$ are obtained from (S)- $\gamma$-hydroxymethyl- $\gamma$-butyrolactone (2H-HBO, 2), itself derived from glutamic acid (Scheme 1) [9-19], a natural amino acid that is produced by fermentation on a commercial scale [20]. Glutamic acid is first deaminated to give the intermediate (S)- $\gamma$-carboxy- $\gamma$-butyrolactone, which was first reported by Austin et al. using nitrous acid [11]. The protocol then evolved in 1978 with the use of a light excess of sodium nitrite and $\mathrm{HCl}$ instead of nitrous acid [12] and, to the best of our knowledge, remains unchanged today [13]. Three different routes have been reported for the reduction of $(S)-\gamma$-carboxy- $\gamma$-butyrolactone into 2 . The first one is a 2-step procedure involving the esterification of the carboxylic acid followed by its reduction with $\mathrm{NaBH}_{4}[12,14-16]$. The second route is quite similar but uses an acid chloride instead of the carboxylic acid [10]. Finally, the third and last route consists of a one-step reduction of the carboxylic acid into the alcohol in presence of borane-methylsulfide $\left(\mathrm{BH}_{3}-\mathrm{Me}_{2} \mathrm{~S}\right)[3,17]$ or borane-THF [18]. It is noteworthy that the substitution of borane-methylsulfide by borane-THF to obviate odor problems on large scale [12,19] resulted in over-reduction to the lactol [16]. Although these three routes provide 2 in good yields, they either require two steps or use a carcinogenic reagent (i.e., $\mathrm{BH}_{3}-\mathrm{Me}_{2} \mathrm{~S}$ ). The epoxides are then obtained via the tosylation of $\mathbf{2}$ followed by treatment with sodium alkoxide.<smiles>N[C@@H](CCC(=O)O)C(=O)O</smiles>

L-glutamic acid

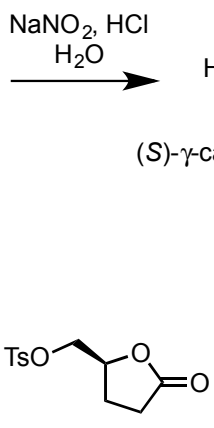

$3 a$



- $\gamma$-carboxy- $\gamma$-butyrolactone

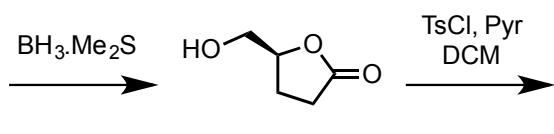

2

Scheme 1. Synthesis of epoxides (S)-1a/1b from L-glutamic acid [3,17].

Recently, we reported on the eco-friendly synthesis of 2 by a chemo-enzymatic process from levoglucosenone (LGO) [21-25] a valuable chiral chemical platform obtained from flash pyrolysis of cellulosic residues, such as softwood sawdust (Furacell ${ }^{\mathrm{TM}}$ process) [26]. Providing $\mathbf{2}$ in very good yield and high purity through a lipase-based mediated oxidation, this sustainable synthetic pathway has been studied further by our group as an alternative to the one involving L-glutamic acid to achieve the synthesis of epoxides (S)-1a and (S)-1b (Scheme 2). 


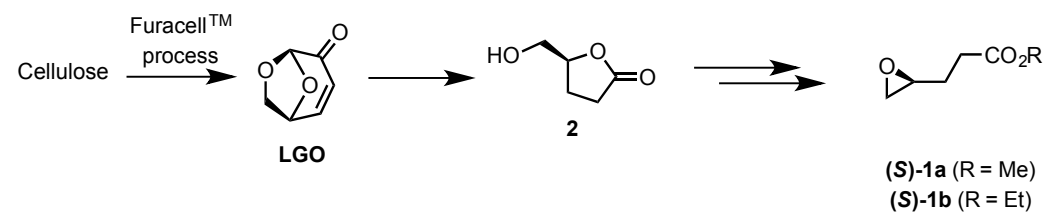

Scheme 2. Synthesis of epoxides (S)-1a/1b from levoglucosenone (LGO).

Dairy lactone is the common name given by flavor specialists to (Z)-5-(oct-2-en-1-yl) dihydrofuran-2(3H)-one (6) (CAS 18679-18-0) of unspecified enantiomeric purity. This lactone, which occurs naturally in cows' milk and also the mycelia of Fusarium poae, exhibits a very fruity nuanced odor (also described as fatty, waxy) as well as a creamy and dairy-like taste, hence its name $[27,28]$. Dairy lactone is commonly used in as flavor for bakery and milk products at up to $1 \mathrm{ppm}$, imitation dairy at $5 \mathrm{ppm}$, and fruit sorbet at $1 \mathrm{ppm}$ [29]. Despite its very attractive flavoring properties, commercial production of dairy lactone remains relatively low (ca. $50 \mathrm{~kg} /$ year worldwide). Indeed, not only is it produced using a costly fermentation process (dairy lactone is sold at ca. 10,000 €/ kg) [30] but some customers also complain of a rancid aftertaste in some batches of the flavor. Under these considerations, an enantioselective synthetic route to individual $S$ and $R$ enantiomers of 6 that leads to the commercial production of pure enantiomers is attractive as a solution to these problems (i.e., production cost and aftertaste). While the enantiomeric composition of commercial dairy lactone appears not to have been published, there is at least one publication that states that the $S$-enantiomer from Fusarium poae is some 3 times stronger in stimulating olefactory response in humans than the $R$-enantiomer [28]. Two synthetic pathways have been reported for the preparation of (S)-dairy lactone (Scheme 3). The first one, reported by Habel et al. [31] starts from an enantiopure glycidyl alkene and involves an alkynylation with heptynyl lithium followed by an osmium tetroxide-mediated oxidative cleavage of the double bound to form the lactone, and finally a syn-hydrogenation of the triple bound. The second pathway developed by Falck consists of the addition of the high order cuprate generated from $(Z)$-1-iodo-hept-1-ene onto the epoxides 1a $[1,32,33]$. Considering that $(Z)$-1-iodo-hept-1-ene needs to be synthesized prior to cuprate formation and that its synthesis involves the use of $\mathrm{CuCN}$ and low temperature $\left(-78^{\circ} \mathrm{C}\right)$, the nucleophilic addition of lithiated 1-heptyne on glycidyls $(S)-1 \mathbf{a} / \mathbf{1} \mathbf{b}$ followed by a syn-hydrogenation of the triple bound (as described in scheme 3-New route), which is a simpler and safer way to perform this synthesis, has been devised and is described herein.

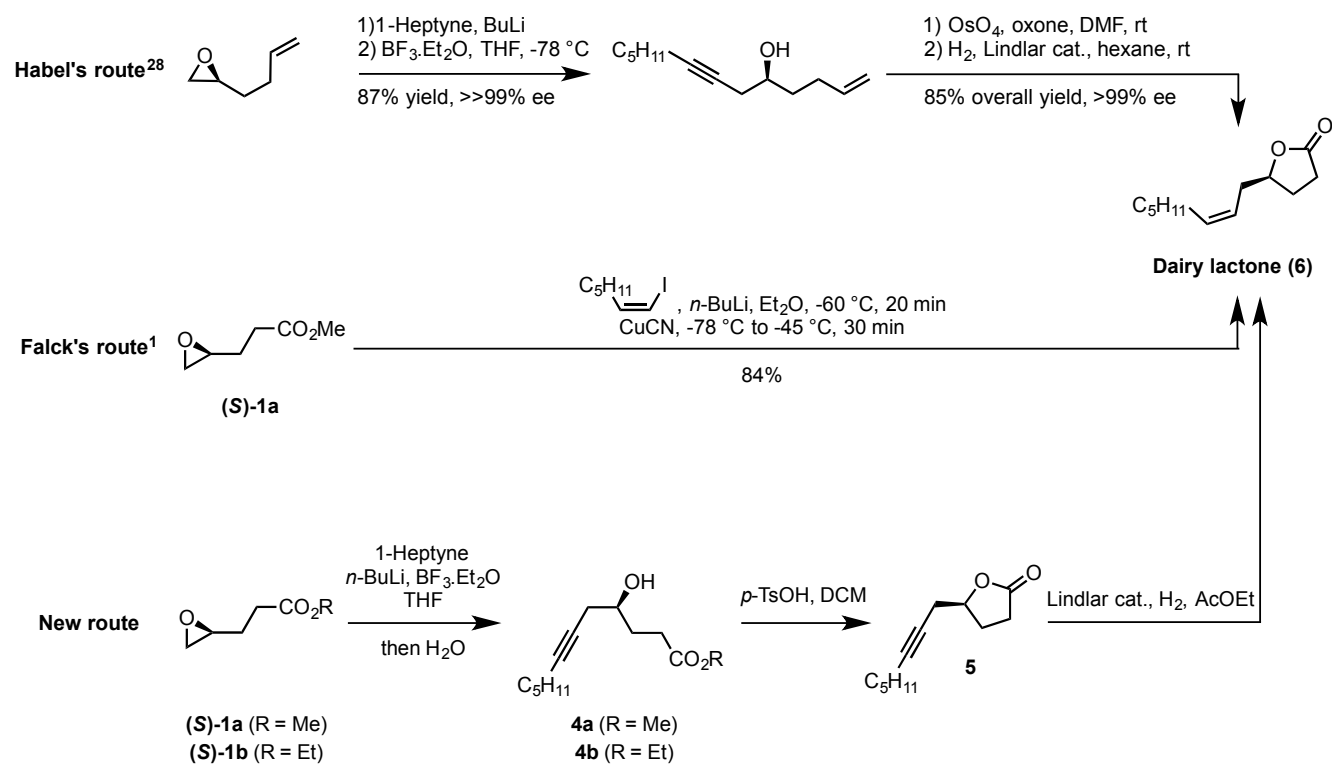

Scheme 3. Synthetic routes to (S)-dairy lactone (6). 
The efficiency (in terms of yield) and green aspects of these new synthetic pathways to ethyl and methyl (S)-3-(oxiran-2-yl)propanoates as well as (S)-dairy lactone will be discussed with regard to the yields and green aspects of the route involving L-glutamic acid.

\section{Results and Discussion}

Herein, we report the use of LGO as starting material to produce ethyl and methyl (S)-3-(oxiran2-yl)propanoates (1a and 1b). (S)-Dairy lactone 6, a potentially high-value commercial flavor chemical, was then synthesized from the two epoxides via an efficient and straightforward pathway.

\subsection{Synthesis of Epoxides from Levoglucosenone (LGO)}

\subsubsection{Synthesis of (S)- $\gamma$-Hydroxymethyl- $\gamma$-butyrolactone (2)}

The synthesis of the epoxides (S)-1a and (S)-1b started with the preparation of key intermediate (S)- $\gamma$-hydroxymethyl- $\gamma$-butyrolactone (2) from LGO using the two chemo-enzymatic pathways we previously developed and optimized [24,25] (Scheme 4). The first one consisted in performing a palladium-catalyzed hydrogenation of LGO $(87 \%)$ followed by the Baeyer-Villiger oxidation of the resulting saturated LGO (2H-LGO, or Cyrene ${ }^{\mathrm{TM}}$ ) in ethyl acetate and in the presence of hydrogen peroxide and CAL-B (aka Novozyme $435^{\circledR}, \mathrm{N} 435$ or immobilized lipase Candida antarctica type B); the subsequent acid hydrolysis of the reaction mixture with Amberlyst 15 IR dry in ethanol then provides 2 in $65 \%$ overall yield. The second pathway involves the exact same reactions but in a reversed fashion (i.e., Baeyer-Villiger oxidation of LGO, acid hydrolysis and palladium-catalyzed hydrogenation) providing 2 in 70\% overall yield from LGO.

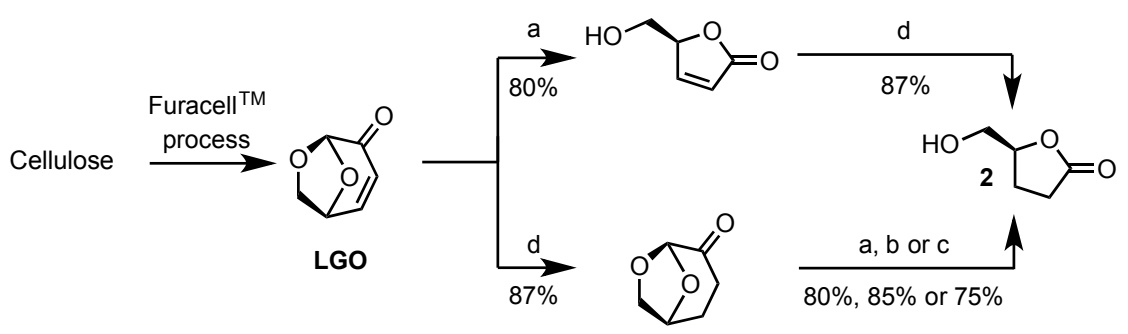

a: CAL-B, $\mathrm{H}_{2} \mathrm{O}_{2}$, AcOEt; b: $m$-CPBA, p-TsOH; c: AcOOH, $\mathrm{H}_{2} \mathrm{O}$; d: $\mathrm{Pd} / \mathrm{C}, \mathrm{H}_{2}$, EtOH

Scheme 4. Syntheses of (S)- $\gamma$-hydroxymethyl- $\gamma$-butyrolactone (2) from cellulose.

It is noteworthy that the above Baeyer-Villiger oxidation of LGO can be performed either chemically—using AcOOH (75\%) [34,35], zeolites (96\% HPLC yield) [36] or $m$-CPBA (85\%) [34,35]—or enzymatically with a lipase (80\%) [24,25]. Even though the $m$-CPBA- and zeolites-based Baeyer-Villiger oxidations lead to slightly better yields, lipase-mediated Baeyer-Villiger oxidation is preferred because it avoids not only the use of potentially explosive organic peroxide and harmful organic solvent (dichloromethane), but also the production of stoichiometric amount of by-product (i.e., $m$-chlorobenzoic acid). In addition, the enzyme is used in catalytic amount and can be easily recycled by simple filtration $[24,25]$.

\subsubsection{Synthesis of Ethyl and Methyl (S)-3-(Oxiran-2-yl)propanoates ((S)-1a and ((S)-1b)}

Ethyl and methyl (S)-3-(oxiran-2-yl)propanoates ((S)-1a and ((S)-1b) were synthesized in two steps from 2 (Scheme 5). The primary hydroxyl moiety in compound 2 was first activated through tosylation (3a, 84\%) and mesylation (3b, 64\%) in pyridine/dichloromethane with $\mathrm{TsCl}$ and $\mathrm{MesCl}$, respectively. Epoxides (S)-1a and (S)-1 b were then efficiently obtained by treating the activated lactones with sodium methoxide or ethoxide. The mechanism involves two steps: (1) nucleophilic attack of sodium methoxide or ethoxide on the lactone to form the corresponding secondary alcoholate 
intermediate; and (2) $\mathrm{S}_{\mathrm{N} 2}$ intramolecular substitution of the tosylate/mesylate by the alkoxide oxygen. Crude methyl-4,5-epoxypentanoate $((S)-1 \mathbf{a})$ and ethyl-4,5-epoxypentanoate $((S)-1 \mathbf{b})$ were thus obtained in $97 \%$ and $96 \%$ yields from $3 \mathbf{a}$ and in $42 \%$ and $86 \%$ yields from $3 \mathbf{b}$, respectively. Once purified by distillation, the optical activity of (S)-1a and (S)-1b were measured and proved in accordance with those already reported in the literature (see Materials and Methods section), demonstrating that no epimerization occurs in the process. In terms of atom economy, using mesylate $\mathbf{3} \mathbf{b}$ would be the greener option; however, tosylate 3a appears as a better choice as it was obtained in better yield, is crystalline allowing for simple purification and also proved more reactive in the next step. Alternatively, if sodium methoxide and ethoxide give the same yield, the latter will be preferred due to the lower toxicity of ethanol compared to methanol.

Starting from LGO, the most efficient synthetic route in terms of yield is the one involving tosyl chloride and sodium methoxide ( $81 \%$ overall yield). The greener route, that involves mesyl chloride and sodium ethoxide provides the chiral epoxides in $60 \%$ overall yield.
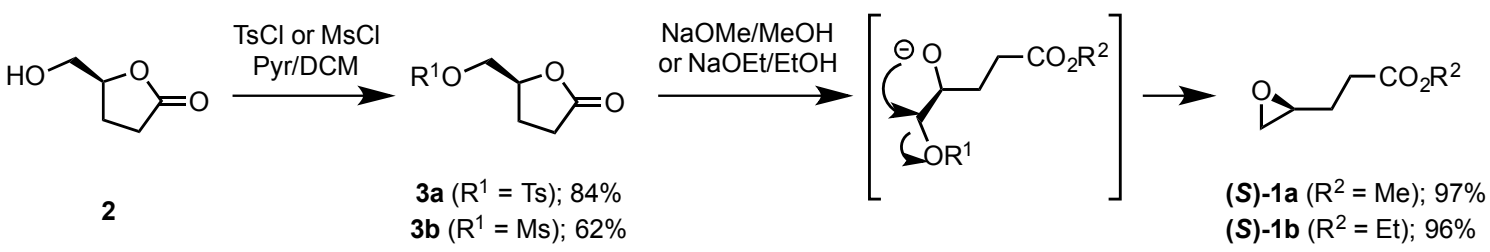

Scheme 5. Syntheses of epoxides (S)-1a/1b from (S)- $\gamma$-hydroxymethyl- $\gamma$-butyrolactone (2).

\subsection{Synthesis of (S)-Dairy Lactone}

(S)-Dairy lactone was thus synthesized in three steps from epoxides: (1) regioselective opening of the epoxides, (2) acid-mediated lactonization, and (3) syn-stereoselective hydrogenation (Scheme 6). The Lewis acid-mediated opening of the epoxide in the presence of lithiated hept-1-yne resulted in the addition of the latter on the less substituted carbon, providing $\gamma$-hydroxyesters $\mathbf{4 a}$ and $\mathbf{4 b}$. Acid-catalyzed lactonization of crude $4 \mathbf{a}$ or $4 \mathrm{~b}$ was then performed in presence of $p$-toluenesulfonic acid to give lactone 5 in 45\% and 74\% yields, respectively. Finally, (S)-dairy lactone 6 was obtained via syn-selective hydrogenation of the alkyne moiety by using Lindlar palladium catalyst (94\% yield). In summary, $(S)$-dairy lactone was successfully synthesized in seven steps and in $37 \%$ overall yield from LGO (69\% overall yield from $(S)-\mathbf{1 a} /(S)-\mathbf{1 b})$.

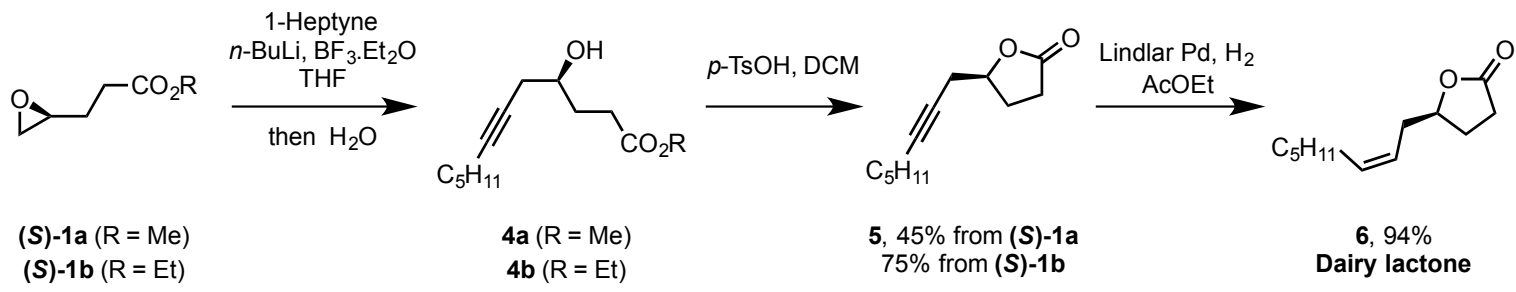

Scheme 6. Synthesis of (S)-dairy lactone from epoxide $(S)-\mathbf{1 a} \mathbf{a} \mathbf{1} \mathbf{b}$.

\section{Materials and Methods}

Levoglucosenone (LGO) was kindly supplied by Circa Group. Novozyme $435^{\circledR}$ (aka N435, immobilized lipase Candida antarctica type B or CAL-B) was purchased from Univar. Other reagents were purchased from Sigma-Aldrich and used as received. Solvents were purchased from ThermoFisher Scientific. When necessary, they were dried on mBraun SPS $800 . \mathrm{CDCl}_{3}$ was purchased from Euriso-top. Evaporations were conducted under reduced pressure at temperature below $40{ }^{\circ} \mathrm{C}$. Column chromatography was carried out with an automated flash chromatography (PuriFlash 4100, Interchim) and pre-packed INTERCHIM PF-30SI-HP (30 $\mu \mathrm{m}$ silica gel) columns. IR and UV analyses 
were performed on Cary 630 FTIR and Cary 60 UV-Vis from Agilent technologies, respectively. NMR analyses were recorded on a Bruker Fourier 300. ${ }^{1} \mathrm{H}-\mathrm{NMR}$ spectra of samples were recorded in $\mathrm{CDCl}_{3}$ at $300 \mathrm{MHz}$, chemical shifts were reported in parts per million relative to residual solvent peak $(\delta=7.26 \mathrm{ppm}) .{ }^{13} \mathrm{C}-\mathrm{NMR}$ spectra of samples were recorded at $75 \mathrm{MHz}\left(\mathrm{CDCl}_{3}\right.$ residual signal at $\delta=77.16 \mathrm{ppm})$.

\subsection{Chemo-Enzymatic Synthesis of (S)- $\gamma$-Hydroxymethyl- $\gamma$-butyrolactone (2)}

N435 (237 PLU/mmol of LGO) was suspended in ethyl acetate $(210 \mathrm{~mL}, c=0.75 \mathrm{M})$, then LGO (20 g, $159 \mathrm{mmol})$ and finally $\mathrm{H}_{2} \mathrm{O}_{2}(30 \% w / w$ in water, $18 \mathrm{~mL}, 159 \mathrm{mmol}, 1$ equiv) were added. The reaction mixture was incubated at $40{ }^{\circ} \mathrm{C}$ and $150 \mathrm{rpm}$ during $16 \mathrm{~h}$. Then, N435 was filtered off and ethyl acetate was removed under reduced pressure. Crude residue was diluted with ethanol $(40 \mathrm{~mL})$ and added to a suspension of Amberlyst 15 IR dry $(40 \mathrm{~g})$ in ethanol $(80 \mathrm{~mL})$. After a night of incubation at $37^{\circ} \mathrm{C}$ and $150 \mathrm{rpm}$, Amberlyst was filtered off. The crude mixture was flushed with nitrogen and $10 \% w$ palladium on carbon $(2 \mathrm{~g})$ was added, the reaction was then stirred at atmospheric pressure under hydrogen flux for a night. The crude mixture was filtered through a pad of Celite ${ }^{\circledR}$ and the filtrate was concentrated to dryness. The resulting orange oil was purified by silica gel chromatography (elution with 50 to $100 \%$ ethyl acetate in cyclohexane) to yield pure $2 \mathbf{H}-\mathbf{H B O}(2)$ as a colorless oil $(70 \%)$; $[\alpha]_{\mathrm{D}}^{20}+52.9^{\circ}\left(c 0.01, \mathrm{CHCl}_{3}\right) ;$ Lit. [26] $+55.2^{\circ}\left(c 0.1, \mathrm{CHCl}_{3}\right) ; \mathrm{UV}(\mathrm{EtOH}) \lambda_{\max } 207 \mathrm{~nm}$; FT-IR (neat, $\left.\mathrm{cm}^{-1}\right)$ : $3420(\mathrm{OH}), 2938,1752(\mathrm{C}=\mathrm{O}), 1353,1181 ;{ }^{1} \mathrm{H}-\mathrm{NMR}\left(\mathrm{CDCl}_{3}, 300 \mathrm{MHz}\right): \delta 2.20$ (m, 2H, H-3), 2.61 (m, 3H, H-2a, H-2b, OH), 3.66 (dd, $1 \mathrm{H}, J=12.6$ and $4.5 \mathrm{~Hz}, \mathrm{H}-5 \mathrm{a}$ ), 3.92 (dd, $1 \mathrm{H}, J=12.6$ and $2.7 \mathrm{~Hz}, \mathrm{H}-5 \mathrm{~b}), 4.64$ $(\mathrm{m}, 1 \mathrm{H}, \mathrm{H}-4) ;{ }^{13} \mathrm{C}-\mathrm{NMR}\left(\mathrm{CDCl}_{3}, 75 \mathrm{MHz}\right): \delta 23.1(\mathrm{t}, \mathrm{C}-2), 28.7(\mathrm{t}, \mathrm{C}-3), 64.1(\mathrm{t}, \mathrm{C}-5), 80.8(\mathrm{~d}, \mathrm{C}-4), 177.7$ (s, C-1); HRMS: $m / z$ [M + Na] $]^{+}$calcd for $\mathrm{C}_{5} \mathrm{H}_{8} \mathrm{NaO}_{3}: 139.0371$, found: 139.0379 .

\subsection{Synthesis of $\mathbf{2}$ Using $m-C P B A$}

To a stirred solution of dihydrolevoglucosenone $(4.0 \mathrm{~g}, 31.2 \mathrm{mmol})$ in dichloromethane $(50 \mathrm{~mL})$ cooled using a water bath was added $70 \%$ meta-chloroperbenzoic acid $(11.5 \mathrm{~g}, 47 \mathrm{mmol})$. $p$ - $\mathrm{TsOH}(800 \mathrm{mg}, 5 \mathrm{mmol})$ was then added and the resulting solution stirred for $16 \mathrm{~h}$. Volatiles were removed under reduced pressure and then $1 \mathrm{M} \mathrm{HCl}(20 \mathrm{~mL})$ was added and the resulting solution stirred overnight. The mixture was filtered, the precipitate washed with water and the filtrate concentrated under reduced pressure. Purification of the residue by flash chromatography to remove residual $m$-chloroperbenzoic acid afforded 2 as colorless crystals $(3.07 \mathrm{~g}, 85 \%)$.

\subsection{Synthesis of (S)- $\gamma$-Tosyloxymethyl- $\gamma$-butyrolactone (3a)}

Under nitrogen, $2(2.5 \mathrm{~g}, 21.5 \mathrm{mmol})$ and $p$-toluenesulfonyl chloride $(6.16 \mathrm{~g}, 32.3 \mathrm{mmol}, 1.5 \mathrm{equiv})$ were dissolved in a mixture of dry dichloromethane $(10 \mathrm{~mL})$ and pyridine $(4.3 \mathrm{~mL})$ and stirred at room temperature for $9 \mathrm{~h}$. The reaction mixture was diluted with dichloromethane $(100 \mathrm{~mL})$, washed thrice with $\mathrm{HCl}$ solution $(3 \mathrm{M}, 50 \mathrm{~mL})$, and twice with a saturated solution of $\mathrm{NaHCO}_{3}(50 \mathrm{~mL})$ and with brine $(50 \mathrm{~mL})$. The organic layer was then dried over anhydrous $\mathrm{MgSO}_{4}$, filtered and concentrated. The crude mixture was triturated in $\mathrm{Et}_{2} \mathrm{O}(20 \mathrm{~mL})$ to yield $3 \mathbf{a}$ as a beige powder $(4.88 \mathrm{~g}$, 84\%); m.p.: $83.3^{\circ} \mathrm{C} ;[\alpha]_{\mathrm{D}}^{20}+47.9^{\circ}\left(c 0.11, \mathrm{CHCl}_{3}\right)$; Lit. [7] +44.5 (c 0.95, $\left.\mathrm{CHCl}_{3}\right)$; $\mathrm{UV}\left(\mathrm{CDCl}_{3}\right) \lambda_{\max } 237$, 263, 274 nm; FT-IR (neat): 2961, 1765 (C=O), 1595 (C=Carom), 1448 (C=Carom), 1364, $1169 \mathrm{~cm}^{-1}$; ${ }^{1} \mathrm{H}-\mathrm{NMR}\left(\mathrm{CDCl}_{3}, 300 \mathrm{MHz}\right): \delta 2.25$ (m, 2H, H-3), 2.45, (s, 3H, H-10), 2.55 (m, 2H, H-2), 4.16 (m, 2H, H-5), $4.68(\mathrm{~m}, 1 \mathrm{H}, \mathrm{H}-4), 7.36$ (d, 2H, $J=8.1 \mathrm{~Hz}, \mathrm{H}-8), 7.78(\mathrm{~d}, 2 \mathrm{H}, J=8.1 \mathrm{~Hz}, \mathrm{H}-7) ;{ }^{13} \mathrm{C}-\mathrm{NMR}\left(\mathrm{CDCl}_{3}, 75 \mathrm{MHz}\right)$ : $\delta 21.8(\mathrm{q}, \mathrm{C}-10), 23.7(\mathrm{t}, \mathrm{C}-2), 28.0(\mathrm{t}, \mathrm{C}-3), 70.1$ (t, C-5), 76.5 (d, C-4), 128.1 (d, C-7), $130.2(\mathrm{~d}, \mathrm{C}-8), 132.3$ (s, C-9), 145.6 (s, C-6), 176.2 (s, C-1).

\subsection{Synthesis of (S)- $\gamma$-Mesyloxymethyl- $\gamma$-butyrolactone ( $\mathbf{3 b})$}

Under nitrogen, 2 ( $5.0 \mathrm{~g}, 43.1 \mathrm{mmol})$ and methanesulfonyl chloride (5.0 mL, $64.7 \mathrm{mmol}, 1.5$ equiv), were dissolved in a mixture of dry dichloromethane $(22 \mathrm{~mL})$ and pyridine $(8.7 \mathrm{~mL})$ and stirred at room temperature for $3 \mathrm{~h}$. The reaction mixture was diluted with dichloromethane $(200 \mathrm{~mL})$, 
washed thrice with $\mathrm{HCl}$ solution $(3 \mathrm{M}, 100 \mathrm{~mL})$, twice with a saturated solution of $\mathrm{NaHCO}_{3}(100 \mathrm{~mL})$ and with brine $(100 \mathrm{~mL})$. The organic layer was then dried over anhydrous $\mathrm{MgSO}_{4}$, filtered and concentrated. The crude mixture was triturated in $\mathrm{Et}_{2} \mathrm{O}(40 \mathrm{~mL})$ to yield $3 \mathbf{b}$ as a beige powder (5.2 g, 62\%); m.p.: $46.5^{\circ} \mathrm{C} ;[\alpha]_{\mathrm{D}}^{20}+30.6^{\circ}\left(c 0.10, \mathrm{CHCl}_{3}\right)$; Lit. [15] +33.7 $\left(c 1, \mathrm{CHCl}_{3}\right)$; FT-IR (neat): 3012, 2936, $1758(\mathrm{C}=\mathrm{O}), 1338,1157 \mathrm{~cm}^{-1},{ }^{1} \mathrm{H}-\mathrm{NMR}\left(\mathrm{CDCl}_{3}, 300 \mathrm{MHz}\right): \delta 2.12(\mathrm{~m}, 1 \mathrm{H}, \mathrm{H}-3 \mathrm{a}), 2.36(\mathrm{~m}, 1 \mathrm{H}$, $\mathrm{H}-3 \mathrm{~b}), 2.56$ (m, 2H, H-2), 3.05 (s, 3H, H-6), 4.26 (m, 1H, H-5a), 4.42, (m, 1H, H-5b), 4.75 (m, 1H, H-4); ${ }^{13} \mathrm{C}-\mathrm{NMR}\left(\mathrm{CDCl}_{3}, 75 \mathrm{MHz}\right): \delta 23.4(\mathrm{t}, \mathrm{C}-3), 28.0(\mathrm{t}, \mathrm{C}-2), 37.7(\mathrm{q}, \mathrm{C}-6), 70.0(\mathrm{t}, \mathrm{C}-5), 76.8(\mathrm{~d}, \mathrm{C}-4), 176.3$ $(\mathrm{s}, \mathrm{C}-1)$.

\subsection{Synthesis of (S)-Methyl 4,5-epoxypentanoate ((S)-1a) and (S)-Ethyl 4,5-epoxypentanoate ((S)-1b)}

Under nitrogen, $3 \mathbf{a}(2.0 \mathrm{~g}, 7.37 \mathrm{mmol})$ or $3 \mathbf{b}(1.4 \mathrm{~g}, 7.37 \mathrm{mmol})$ was dissolved in $\mathrm{MeOH} / \mathrm{EtOH}$ $(10 \mathrm{~mL})$ and sodium methoxide ( $400 \mathrm{mg}, 1.1$ equiv)/sodium ethoxide (510 mg, 1.1 equiv) was added. The reaction was stirred at room temperature for $3 \mathrm{~h}$ and then the solvent was evaporated and water $(10 \mathrm{~mL})$ was added. The aqueous layer was extracted twice with $\mathrm{Et}_{2} \mathrm{O}(15 \mathrm{~mL})$, the organic layers were combined, washed with brine $(20 \mathrm{~mL})$, dried over anhydrous $\mathrm{MgSO}_{4}$ and concentrated to dryness.

(S)-1a $(0.93 \mathrm{~g}, 97 \%)$ orange oil. A small quantity of the product was distilled under reduced pressure to give a colorless oil. $[\alpha]_{\mathrm{D}}^{20}-17.0^{\circ}\left(c 0.11, \mathrm{CHCl}_{3}\right)$; Lit. [7] $-17.9^{\circ}\left(c 7.4, \mathrm{CHCl}_{3}\right)$; FT-IR (neat): 2952, 1731 (C=O), 1437, 1360, 1256, $1172 \mathrm{~cm}^{-1},{ }^{1} \mathrm{H}-\mathrm{NMR}\left(\mathrm{CDCl}_{3}, 300 \mathrm{MHz}\right): \delta 1.78$ (m, 1H, H-3a), 1.98 (m, 1H, H-3b), 2.48 (m, 3H, H-2, H-5a), 2.77 (m, 1H, H-5b), 2.98 (m, 1H, H-4), 3.69 (s, 3H, H-6); ${ }^{13} \mathrm{C}-\mathrm{NMR}\left(\mathrm{CDCl}_{3}, 75 \mathrm{MHz}\right): \delta 27.7(\mathrm{t}, \mathrm{C}-3), 30.3(\mathrm{t}, \mathrm{C}-2), 47.2(\mathrm{t}, \mathrm{C}-5), 51.4(\mathrm{~d}, \mathrm{C}-4), 51.8(\mathrm{q}, \mathrm{C}-6), 173.4$ $(\mathrm{s}, \mathrm{C}-1)$.

(S)-1b (1.02 g, 96\%) orange oil. A small quantity of the product was distilled under reduced pressure to give a colorless oil. FT-IR (neat, $\left.\mathrm{cm}^{-1}\right): 2982,1729(\mathrm{C}=\mathrm{O}), 1371,1254,1176 ;[\alpha]_{\mathrm{D}}^{20}-15.6^{\circ}$ (c 0.11, $\left.\mathrm{CHCl}_{3}\right)$; Lit. [15] - 17.1 ${ }^{\circ}\left(c\right.$ 0.8, $\left.\mathrm{CHCl}_{3}\right) ;{ }^{1} \mathrm{H}-\mathrm{NMR}\left(\mathrm{CDCl}_{3}, 300 \mathrm{MHz}\right): \delta 1.22(\mathrm{td}, 3 \mathrm{H}, J=7.2$ and $1.2 \mathrm{~Hz}, \mathrm{H}-7), 1.74$ (m, 1H, H-3), 1.92 (m, 1H, H-3), 2.42 (m, 3H, H-2, H-5), 2.72 (m, 1H, H-5), 2.94 (m, 1H, $\mathrm{H}-4), 4.10$ (qd, 2H, J = 7.2 and $1.2 \mathrm{~Hz}, \mathrm{H}-6) ;{ }^{13} \mathrm{C}-\mathrm{NMR}\left(\mathrm{CDCl}_{3}, 75 \mathrm{MHz}\right): \delta 14.4$ (q, C-7), 27.8 (t, C-3), $30.6(\mathrm{t}, \mathrm{C}-2), 47.2(\mathrm{t}, \mathrm{C}-5), 51.4(\mathrm{~d}, \mathrm{C}-4), 60.7(\mathrm{t}, \mathrm{C}-6), 173.0(\mathrm{~s}, \mathrm{C}-1)$.

\subsection{Synthesis of (S)-5-(Oct-2-yn-1-yl)- $\gamma$-butyrolactone (5)}

Under nitrogen at $-78^{\circ} \mathrm{C}$, 1-heptyne $(1.0 \mathrm{~mL}, 7.53 \mathrm{mmol}, 1.4$ equiv) was dissolved in dry THF (11 mL), then $n$-butyl lithium $2.5 \mathrm{M}$ in hexane $(3.0 \mathrm{~mL}, 7.53 \mathrm{mmol}, 1.4$ equiv) was added. After $5 \mathrm{~min}$, boron trifluoride etherate $(0.93 \mathrm{~mL}, 7.53 \mathrm{mmol}, 1.4$ equiv) was added, and $30 \mathrm{~min}$ later, $(S)-1 \mathrm{a}(0.70 \mathrm{~g}$, $5.38 \mathrm{mmol}, 1$ equiv), or $(S)-\mathbf{1 b}(0.78 \mathrm{~g}, 5.38 \mathrm{mmol}, 1$ equiv), was added. The reaction media was stirred at $-78{ }^{\circ} \mathrm{C}$ for $3 \mathrm{~h}$, then quenched with a saturated solution of $\mathrm{NaHCO}_{3}(6 \mathrm{~mL})$ and water $(50 \mathrm{~mL})$ was added. The aqueous layer was extracted with dichloromethane $(3 \times 20 \mathrm{~mL})$. The organic layers were combined, washed with brine, dried over anhydrous $\mathrm{MgSO}_{4}$ and concentrated to dryness. The crude product was diluted in dichloromethane $(50 \mathrm{~mL})$ and $p$ - TsOH monohydrate $(270 \mathrm{mg}, 1.4 \mathrm{mmol}$, 0.25 equiv) was added. After $3 \mathrm{~h}$, the reaction was quenched with a saturated solution of $\mathrm{NaHCO}_{3}$. The organic layer was dried over anhydrous $\mathrm{MgSO}_{4}$, filtered and concentrated. The orange oil was purified by silica gel chromatography (elution with $95 \%$ to $90 \%$ ethyl acetate in cyclohexane) to yield pure 5 as a yellow oil $(70 \%$ from $(S)-1 \mathbf{b}$ and $45 \%$ from $(S)-1 \mathbf{a})$; $[\alpha]_{\mathrm{D}}^{20}-29.5^{\circ}\left(c 0.12, \mathrm{CHCl}_{3}\right)$; FT-IR (neat, $\mathrm{cm}^{-1}$ ): 2929, 2858, $1772(\mathrm{C}=\mathrm{O}), 1349,1172 ;{ }^{1} \mathrm{H}-\mathrm{NMR}\left(\mathrm{CDCl}_{3}, 300 \mathrm{MHz}\right): \delta 0.89$ (m, 3H, H-12), 1.31 (m, 4H, H-10, H-11), 1.47 (m, 2H, H-9), 2.13 (m, 3H, H-3, H-8), 2.38 (m, 1H, H-3), 2.58 (m, 4H, $\mathrm{H}-2, \mathrm{H}-5), 4.60$ (m, 1H, H-4); ${ }^{13} \mathrm{C}-\mathrm{NMR}\left(\mathrm{CDCl}_{3}, 75 \mathrm{MHz}\right): \delta 14.1$ (q, C-12), 18.7 (t, C-8), 22.3 (t, C-11), $25.6(\mathrm{t}, \mathrm{C}-5), 26.6$ (t, C-3), $28.6(\mathrm{t}, \mathrm{C}-2, \mathrm{C}-9), 31.1$ (t, C-10), 73.6 (s, C-6), $78.2(\mathrm{~d}, \mathrm{C}-4), 83.7$ (s, C-7), 177.0 (s, C-1).

\subsection{Synthesis of (S)-Dairy Lactone (6)}

$5(2.72 \mathrm{~g}, 14.0 \mathrm{mmol})$ was dissolved in ethyl acetate $(56 \mathrm{~mL}, c=0.25 \mathrm{M})$ and Lindlar palladium $(0.20 \mathrm{~g}, 7.5 \% w / w)$ was added. The reaction was vigorously stirred under 1 atmosphere of hydrogen 
until complete by GC. The crude mixture was filtered through a pad of Celite ${ }^{\circledR}$ and the filtrate was concentrated to dryness. The resulting orange oil was purified by silica gel chromatography (elution with $20 \%-50 \%$ ethyl acetate in cyclohexane) to yield pure $S$-dairy lactone 6 (2.59 g, 94\%); $[\alpha]_{\mathrm{D}}^{20}+7.5^{\circ}\left(c\right.$ 0.51, $\left.\mathrm{CHCl}_{3}\right)$; Lit. [29] +17.7 $(c$ 0.37, MeOH); FT-IR (neat): 2923, 2854, $1771(\mathrm{C}=\mathrm{O}), 1459$, 1348, $1173 \mathrm{~cm}^{-1},{ }^{1} \mathrm{H}-\mathrm{NMR}\left(\mathrm{CDCl}_{3}, 300 \mathrm{MHz}\right): \delta 0.82$ (m, 3H, H-12), 1.23 (m, 6H, H-9, H-10, H-11), 1.84 (m, 1H, H-3a), 1.98 (m, 2H, H-8), 2.23 (m, 1H, H-3b), 2.37 (m, 1H, H-5a), 2.47 (m, 3H, H-2, H-5b), $4.47(\mathrm{q}, 1 \mathrm{H}, J=6.6 \mathrm{~Hz}, \mathrm{H}-4), 5.29(\mathrm{~m}, 1 \mathrm{H}, \mathrm{H}-6), 5.51(\mathrm{~m}, 1 \mathrm{H}, \mathrm{H}-7) ;{ }^{13} \mathrm{C}-\mathrm{NMR}\left(\mathrm{CDCl}_{3}, 75 \mathrm{MHz}\right): \delta 14.0$ (q, C-12), 22.5 (t, C-10), 27.1 (t, C-3), $27.4(\mathrm{t}, \mathrm{C}-8), 28.7(\mathrm{t}, \mathrm{C}-2), 29.1(\mathrm{t}, \mathrm{C}-11), 31.4(\mathrm{t}, \mathrm{C}-9), 32.8(\mathrm{t}, \mathrm{C}-5)$, 80.2 (d, C-4), 122.2 (d, C-6), 134.0 (d, C-7), 177.1 (s, C-1).

${ }^{1} \mathrm{H}$ - and ${ }^{13} \mathrm{C}-\mathrm{NMR}$ spectra for compounds $\mathbf{2}, \mathbf{3 a}, \mathbf{3 b}$, crude $(S)-\mathbf{1 a}$, crude $(S)-\mathbf{1 b}, \mathbf{5}$ and $\mathbf{6}$ can be found in Supplementary Materials.

\section{Conclusions}

A greener and more efficient synthetic method to access chiral epoxides ethyl and methyl (S)-3-(oxiran-2-yl)propanoates has been developed from renewable levoglucosenone using a lipase-mediated enzymatic Baeyer-Villiger oxidation. The total synthesis of (S)-dairy lactone has then been successfully achieved in three steps and in $69 \%$ overall yield from these chiral epoxides using alkynylation with heptynyl lithium, and Lindlar catalyst-mediated syn-hydrogenation as the key steps.

Supplementary Materials: Supplementary materials can be accessed at: http://www.mdpi.com/1420-3049/21/ 8/988/s1.

Acknowledgments: The authors are grateful to the Region Champagne-Ardenne, the Conseil Départemental de la Marne and Reims Métropole for their financial support.

Author Contributions: A.A.M.P., B.W.G. and F.A. conceived and designed the experiments; A.A.M.P., M.J. performed the experiments; A.A.M.P., A.L.F., M.J., B.W.G. and F.A. analyzed the data; C.G. and W.R. contributed reagents; A.L.F., W.R., B.W.G. and F.A. wrote the paper.

Conflicts of Interest: The authors declare no conflict of interest.

\section{References}

1. Shin, D.-S.; Yadagiri, P.; Falck, J.R. Synthesis and Structure of Compound D, A Proinflammatory Arachidonate Metabolite. Tetrahedron Lett. 1989, 30, 3923-3926. [CrossRef]

2. Haynes, S.W.; Sydor, P.K.; Corre, C.; Song, L.; Challis, G.L. Stereochemical Elucidation of Streptorubin B. J. Am. Chem. Soc. 2011, 133, 1793-1798. [CrossRef] [PubMed]

3. Montagnat, O.D.; Lessene, G.; Hugues, A.B. Synthesis of Azide-Alkyne Fragments for "Click" Chemical Applications. Part 2. Formation of Oligomers from Orthogonally Protected Chiral Trialkylsilylhomopro pargyl Azides and Homopropargyl Alcohols. J. Org. Chem. 2010, 75, 390-398. [CrossRef] [PubMed]

4. Zunszain, P.A.; Varela, O. Two approaches to the enantioselective synthesis of (4R)-(-)-4-hydroxymethyl-4thiobutyro-1,4-lactone. Tet. Asymmetry 2000, 11, 765-771. [CrossRef]

5. Denmark, S.E.; Ahmad, M. Carbonylative ring opening of terminal epoxides at atmospheric pressure. J. Org. Chem. 2007, 72, 9630-9634. [CrossRef] [PubMed]

6. Liu, Z.-Y.; Ji, J.-X.; Li, B.-G. The conversion of racemic terminal epoxides into either (+)- or (-)-diol-gamma and delta-lactones. J. Chem. Soc. Perkin Trans. 1 2000, 20, 3519-3521. [CrossRef]

7. Lamb, J.R.; Jung, Y.; Coates, G.W. Meinwald-type rearrangement of monosubstituted epoxides to methyl ketones using an $[\mathrm{Al} \text { porphyrin }]^{+}\left[\mathrm{Co}(\mathrm{CO})_{4}\right]^{-}$catalyst. Org. Chem. Front. 2015, 2, 346-349. [CrossRef]

8. Ugurchieva, T.M.; Lozanova, A.V.; Zlokazov, M.V.; Veselovsky, V.V. Synthesis of (+/-)-4-alkanolides from pent-4-enoic acid. Russ. Chem. Bull. 2008, 57, 657-659. [CrossRef]

9. Ho, P.-T.; Davies, N. A Practical synthesis of $(R)-(-)-\gamma$-Hydroxymethyl- $\gamma$-butyrolactone from Natural Glutamic Acid. Synthesis 1983, 462. [CrossRef]

10. Eguchi, C.; Kakuta, A. The novel synthesis of L-hydroxyproline from D-glutamic acid. Bull. Chem. Soc. Jpn. 1974, 47, 1704-1708. [CrossRef] 
11. Austin, A.T.; Howard, J. The Reaction of Nitrous Acid with Glutamine and Glutamic acid. J. Chem. Soc. 1961, 702, 3593-3603. [CrossRef]

12. Ravid, U.; Silverstein, A.M.; Smith, L.R. Synthesis of the Enantiomers of 4-Susstituted $\gamma$-Lactones with Known Absolute Configuration. Tetrahedron 1978, 34, 1449-1452. [CrossRef]

13. Ma, Z.; Wang, X.; Wang, X.; Rodriguez, R.A.; Moore, C.E.; Gao, S.; Tan, X.; Ma, Y.; Rheingold, A.L.; Baran, P.S.; et al. Asymmetric syntheses of sceptrin and massadine and evidence for biosynthetic enantiodivergence. Science 2014, 346, 219-224. [CrossRef] [PubMed]

14. Taniguchi, M.; Yamada, S. Stereochemical studies-XXX: Stereoselective synthesis of D-ribose from L-glutamic acid. Tetrahedron 1974, 30, 3547-3552. [CrossRef]

15. Koga, K.; Taniguchi, M.; Yamada, S.-I. A new synthesis of D-ribose from L-glutamic acid. Tetrahedron Lett. 1971, 12, 263-266. [CrossRef]

16. Figadère, B.; Franck, X.; Cavé, A. A facile and highly chemoselective protection of primary hydroxyl groups with 2-methyl-1-butene. Tetrahedron Lett. 1993, 34, 5893-5894. [CrossRef]

17. Huh, N.; Thompson, C.M. Enantioenriched N-(2-chloroalkyl)-3-acetoxypiperidines as potential cholinotoxic agents. Synthesis and preliminary evidence for spirocyclic aziridinium formation. Tetrahedron 1995, 51, 5935-5950. [CrossRef]

18. Guan, J.; Zou, Y.; Gao, P.; Wu, Y.; Yue, Z. A Total Synthesis of Natural Rhizobialide. Chin. J. Chem. 2010, 28, 1613-1617. [CrossRef]

19. Yoon, N.M.; Pak, C.S.; Krishnamurthy, S.; Stocky, T.P. Selective reductions. XIX. Rapid reaction of carboxylic acids with borane-tetrahydrofuran. Remarkably convenient procedure for the selective conversion of carboxylic acids to the corresponding alcohols in the presence of other functional groups. J. Org. Chem. 1973, 88, 2786-2792. [CrossRef]

20. Kinushita, S. L-Glutamic acid production. In Encyclopedia of Industrial Biotechnology; Wiley: New York, NY, USA, 2010; pp. 1-25.

21. Witczak, Z.J. Levoglucosenone and Levoglucosans: Chemistry and Applications; ATL Press, Inc.: Mount Prospect, IL, USA, 1994.

22. Witczak, Z.J. Levoglucosenone: Chiral Building Block with New Perspectives. In Chemicals and Materials from Renewable Resources; Bozell, J.J., Ed.; ACS Books: Washington, DC, USA, 2001; pp. 81-97.

23. Koshi, K.; Takashi, E.; Kawakami, H.; Matsushita, H.; Naoi, Y.; Itoh, K. A Method for Easy Preparation of Optically Pure (S)-5-Hydroxy-2-penten-4-olide and (S)-5-Hydroxypentan-4-olide. Heterocycles 1990, 31, 423-426.

24. Flourat, A.L.; Peru, A.A.M.; Teixeira, A.R.S.; Brunissen, F.; Allais, F. Chemo-enzymatic synthesis of key intermediates $(S)$ - $\gamma$-hydroxymethyl- $\alpha, \beta$-butenolide and $(S)$ - $\gamma$-hydroxymethyl- $\gamma$-butyrolactone via lipase-mediated Baeyer-Villiger oxidation of Levoglucosenone. Green Chem. 2015, 17, 404-412. [CrossRef]

25. Teixeira, A.R.S.; Flourat, A.L.; Peru, A.A.M.; Brunissen, F.; Allais, F. Lipase-catalyzed Baeyer-Villiger Oxidation of cellulose-derived Levoglucosenone into $(S)-\gamma$-hydroxymethyl- $\alpha, \beta$-butenolide: Optimization by Response Surface Methodology. Front. Chem. 2016, 4, 16. [CrossRef] [PubMed]

26. Court, G.R.; Lawrence, C.H.; Raverty, W.D.; Duncan, A.J. Method for Converting Lignocellulosic Materials into Useful Chemicals. U.S. Patent US20120111714 A1, 6 January 2011.

27. Wilson, R.D. The Flavour of New Zealand Whole Milk Powder. Ph.D. Thesis, Massey University, Palmerston North, New Zealand, 1992.

28. Latrasse, A.; Guichard, E.; Piffaut, C.; Fournier, N.; Dufossé, L. Chirality of the $\gamma$-lactones formed by Fusarium poae INRA 45. Chirality 1993, 5, 379-384. [CrossRef] [PubMed]

29. (Z)-Dairy Lactone. Available online: http://www.thegoodscentscompany.com/data/rw1038301.html (accessed on 6 May 2016).

30. Farbood, M.I.; Mclean, L.B.; Morris, J.A. Fermentation Process for Preparing 10-Hydroxy-C18-carboxylic Acid and Gamma-Dodelactone Derivatives. U.S. Patent EP0578388 B1, 12 January 1998.

31. Habel, A.; Boland, W. Efficient and flexible synthesis of chiral $\gamma$ - and $\delta$-lactones. Org. Biomol. Chem. 2008, 6, 1601-1604. [CrossRef] [PubMed]

32. Yadagiri, P.; Lumin, S.; Falck, J.R. Total Synthesis of 5(S),12(S)- and 5(S),12(R)-Dihydroxyeicosa-6(Z), $8(E), 14(Z)$-Trienoic acids, metabolites of leukotriene $B_{4}$. Tetrahedron Lett. 1989, 30, 429-432. [CrossRef]

33. Schwartzman, M.L.; Falck, J.R. 12-HETrE Analogs and Methods of Use Thereof. U.S. Patent US2002151734 A1, 2 February 2002. 
34. Koseki, K.; Ebata, T.; Kawakami, H.; Matsushita, H.; Itoh, K.; Naoi, Y. Method of Producing (S)-4-Hydroxymethyl- $\gamma$-lactone. U.S. Patent US5112994, 12 May 1992.

35. Koseki, K.; Ebata, T.; Kawakami, H.; Matsushita, H.; Itoh, K.; Naoi, Y. Method of Preparing (S)- $\gamma-$ Hydroxymethyl- $\alpha, \beta$-butenolide. U.S. Patent US4994585, 19 February 1991.

36. Paris, C.; Moliner, M.; Corma, A. Metal-containing zeolites as efficient catalysts for the transformation of highly valuable chiral biomass-derived products. Green Chem. 2013, 15, 2101-2109. [CrossRef]

Sample Availability: Samples of all compounds are available from the authors.

(C) 2016 by the authors; licensee MDPI, Basel, Switzerland. This article is an open access article distributed under the terms and conditions of the Creative Commons Attribution (CC-BY) license (http://creativecommons.org/licenses/by/4.0/). 